\title{
Improvement of energy indicators of conventional electric driving asynchronous motors of non-standard technological equipment at the enterprises for repair of railway rolling stock through the use of energy-saving motors
}

\author{
Oleh Bondar, Oleksii Baliichuk, Oksana Karzova, Roman Krasnov, Oksana Marenych, and Dmytro Ustimenko \\ Dnipro National University of Railway Transport, Department of electrical engineering and electromechanics, 49010, Dnipro, \\ Lazarian Str., 2, Ukraine
}

\begin{abstract}
The purpose of this work is to study the utilization efficiency of electric driving energy-saving motors of non-standard technological equipment meant for repair of railway rolling stock, in terms of improvement of energy performance, i.e. improvement of efficiency factors and power factors, and decrease of power losses as compared with the most commonly used "conventional" asynchronous motors. There are two options for improvement of the energy performance of electric drives of non-standard technological equipment: replacement of a conventional motor with an energy-saving one similar in terms of nominal voltage, rotational speed, power, etc.; changeover of stator winding from "delta" to "star". A special technique has been proposed to determine the effectiveness of this changeover in terms of improvement of energy indicators. Comparison of the real values of the energy indicators of conventional motors and energy-saving motors in the case under consideration is required to perform the technical and economic calculations when solving the problem of the expediency of replacement of conventional asynchronous motors with energy-saving motors in the abovementioned equipment.
\end{abstract}

\section{Introduction}

Nowadays, conventional asynchronous motors (AI, AIR, AIS, etc.) are most commonly used in electric drives of various units of equipment at the enterprises of Ukraine. The total installed power capacity of the motors in Ukraine is approximately $40 \ldots 50$ million kilowatts [1].

A considerable amount of constant speed motors is used in various repair facilities, in particular, in the rolling stock repair providers, i.e. non-standard technological equipment meant for repair of locomotives, railway cars and multiple-unit rolling stock [2].

Technological processes at these enterprises permit the use of an electric drive without speed control, which is the most easy-to-operate, reliable, energy-efficient and cheap.

\section{Analysis of literature data and problem statement}

The improvement of energy performance of electric driving asynchronous motors (improvement of efficiency factor and power factor, decrease of power losses) comes at an opportune time, when energy resource saving has become a priority task $[10,11,12,13]$. The question of energy saving is acute across the globe, but this topic is especially relevant for Ukraine, where the electricity costs per product unit are significantly higher than in the developed countries [1].

In this paper we developed the methodology and conducted research to increase the energy indicators of the electric drives of the abovementioned non-standard technological equipment through the use of energysaving electric motors, which in recent years have found significant application in some countries (USA, Germany, Japan, etc.), but have very limited applicability in Ukraine. Energy-saving motors reduce the electricity costs while in operation due to higher efficiency and power factors $(\cos \varphi)[1,4,14,15,17$, 18, 19 and 20].

A complete set of non-standard technological equipment meant for repair of locomotives, railway cars and multiple-unit rolling stock is taken as a basic hardware [2].

Practice shows that operation of the abovementioned equipment is characterized by the fact that, depending on the technological process and type of rolling stock under repair, the load factor $k_{\mathrm{H}}$ of electric driving motors of a significant number of devices (washing machines, conveyors, lifting mechanisms, etc.) can be equal to 0,2 ... 0.3 depending on the weight of the rolling stock unit under repair. 


$$
k_{\text {н }}=\frac{P_{\mathrm{r}}}{P_{\text {н }}},
$$

where $P_{\mathrm{r}}$ - true (actual) power developed by electric motor;

$P_{\mathrm{H}}$ - nominal (installed) power capacity of electric motor.

At the same time, the nominal rating power of electric driving motor must be such as to make the equipment work properly at maximum load $\left(k_{\mathrm{H}} \approx 1\right)$.

For example, an electric driving asynchronous motor of conventional cleaning machines for cleaning of traction electric motors works when $k_{\mathrm{H}} \approx 1$ in case of cleaning of traction electric motor of the powerful electric freight locomotive, and when $k_{\mathrm{H}} \approx 0,3$ in case of cleaning of traction motor of motor car unit.

The basic hardware includes more than fifty units of equipment fitted with conventional electric driving asynchronous motors. For example, manipulator for bogie frames, manipulator for automatic coupling devices, cleaning machines for cleaning of diesel motors, traction motors, etc.

The electric motor power falls within the range from $0.37 \mathrm{~kW}$ (manipulator for repair of draw clamps) to 150 $\mathrm{kW}$ (automated traction electric motor testing station AIS-TED).

The comparison of actual efficiency factors and power factors $(\cos \varphi)$ of conventional motors and energy-saving motors in terms of different $k_{\mathrm{H}}$ values is required for performing the technical and economic calculations in order to determine the advisability of the use of energy-saving motors. Note the fact that for performing the technical and economic calculations it will suffice it to know the weighted average values of efficiency factors and power factors, depending on the intended load.

\section{Purpose and objectives of research}

The purpose of this work is to assess the feasibility of electric driving energy-saving motors of non-standard technological equipment meant for repair of railway rolling stock in terms of improvement of energy indicators, i.e. improvement of efficiency factor (EF) and power factor $(\cos \varphi)$, and decrease of power losses $(\Delta P)$ as compared with the most commonly used "conventional" asynchronous motors.

\section{Materials and methods of research}

The quantitative improvement of efficiency factor $(\eta)$ and power factor $(\cos \varphi)$ through the replacement of conventional asynchronous motors with energy-saving motors $\left(\right.$ at $\left.k_{\mathrm{H}} \approx 1\right)$ can be estimated using the characteristics shown in Figure $1[1,4]$.

As can be seen from Figure 1, if the nominal rating power of the electric driving motor of any device is
$P_{\mathrm{H}}<3 \mathrm{~kW}$, the replacement of a conventional electric motor with an energy-saving one will produce a gain in the value of $\cos \varphi$ only, whereas there will be a loss in the value of efficiency. For example, this is about a bearing shield assembly and disassembly press RSP-15 $\left(P_{\mathrm{H}}=2 \mathrm{~kW}, 380 \mathrm{~V}\right)$, manipulator for automatic coupling devices KRS-AS $\left(P_{\mathrm{H}}=0,8 \mathrm{~kW}, 380 \mathrm{~V}\right)$ and other equipment. This fact must be taken into account when performing the technical and economic calculations in order to assess the feasibility of replacement of conventional motors with energy-saving ones.

The range of power levels $P_{\mathrm{H}}=3 \ldots 220 \mathrm{~kW}$ includes all values of nominal rating power of the basic set of non-standard equipment $\left(P_{\mathrm{r} \text { max }}=150 \mathrm{~kW}-\right.$ engine of the automated traction electric motor testing station AISTED). Replacement of conventional asynchronous motors with energy-saving motors similar in terms of power in the specified range of power levels improves both efficiency (EF) and performance $(\cos \varphi)$.

Indeed, the power of conventional motors of all devices included in the basic hardware is selected properly and it is unnecessary to change it. In other words, the technical characteristics of energy-saving asynchronous motors (nominal voltage, rotational speed, power, etc.) should be identical (or close) to the technical characteristics of conventional asynchronous motors. Thus, we can use the characteristics shown in Figure 1 [4] to conduct a comparative estimation of conventional asynchronous motors and energy-saving asynchronous motors in terms of energy indicators, which is required for performing the technical and economic calculations in deciding the question of the expediency of replacement of convenient asynchronous motors with energy-saving asynchronous motors in the basic hardware $\left(P_{\mathrm{н}}=3 \ldots 150 \mathrm{~kW}\right)$.

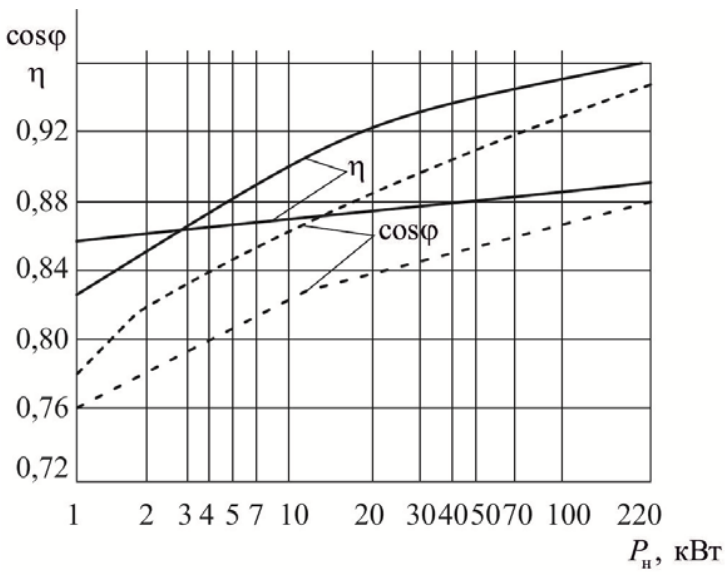

Fig. 1. Comparative estimation of the parameters of conventional asynchronous motors and energy-saving asynchronous motors.

When producing new devices in order to increase the energy indicators of the drive, it is expedient to immediately use the energy-saving motors with the required technical characteristics, if it is possible to acquire them $[8,16]$. 
As noted above, according to the technological conditions, the load factor $k_{\mathrm{H}}$ of the electric driving motors in a significant number of units included in the basic set of non-standard equipment may decrease to 0.2 ... 0.3 depending on the type of rolling stock under repair.

It is known that the energy indicators of an asynchronous motor decrease with the decrease of $k_{\mathrm{н}}$ at the asynchronous motor shaft. In our case, the replacement of electric motors every time in case of underloading to improve the performance is difficult if not impossible according to the technological conditions. Therefore, the expediency of voltage reduction in underloaded asynchronous motors should be checked.

The following voltage reduction methods shall be used for constant speed motors:

- changeover of stator winding from "delta" to "star";

- segmentation of stator winding;

- voltage reduction in the power grids of enterprises by changeover of reducing transformer taps;

Changeover of stator winding from "delta" to "star" is the most easy-to-operate, reliable and cheap method recommended for the asynchronous motors systematically loaded less than $30 \%$ [3] (i.e. when $\left.k_{\mathrm{H}} \leq 0,3\right)$, that is corresponding to the operating conditions of a significant number of units included in the basic set of non-standard equipment. Therefore, in our case, in order to increase the energy indicators of asynchronous motors of the equipment operating with $k_{\mathrm{H}}=0,2 \ldots 0,3$, we recommend to changeover the stator winding from "delta" to "star" [9].

We offer the following methodology for calculation of energy indicators of asynchronous motors at a load factor $k_{\mathrm{H}}<1$ (in our case $k_{\mathrm{H}}=0,2 \ldots 0,3$ ) [5,6]. The technique is based on the equivalent circuit of an asynchronous motor (Figure 2) [7].

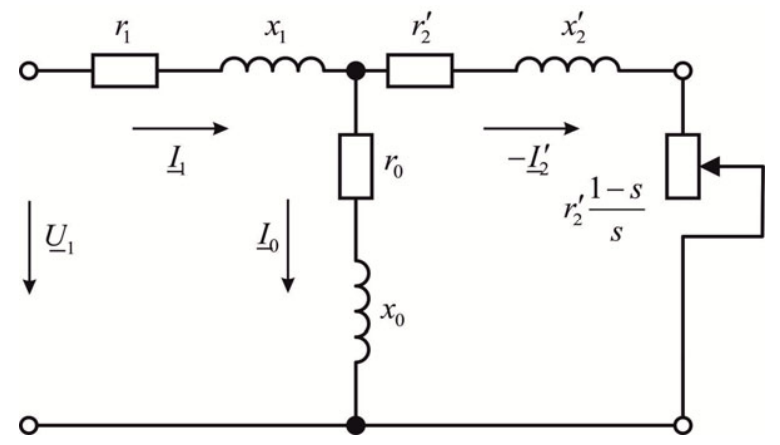

Fig. 2. Equivalent circuit of an asynchronous motor

\section{Proposed calculation algorithm for Delta connection}

1. Nominal value of phase excitation current (no-load current) $I_{\phi 0 \mathrm{H} \Delta}$

$$
I_{\phi 0 \mathrm{H} \Delta} \approx I_{\phi \mathrm{H} \Delta}\left(\sin \varphi_{\mathrm{H}}-\frac{\cos \varphi_{\mathrm{H}}}{b_{\mathrm{H}}+\sqrt{b_{\mathrm{H}}^{2}-1}}\right),
$$

where $I_{\text {фн } \Delta}$ - nominal phase current for "delta" connection;

$\cos \varphi_{\mathrm{H}}-$ power factor of an asynchronous motor in nominal mode;

$b_{\text {н }}$ - maximum torque ratio of an asynchronous motor under nominal load, voltage and frequency.

$$
I_{\phi \mathrm{H} \Delta}=\frac{P_{\mathrm{H}}}{3 U_{\phi \mathrm{H} \Delta} \cos \varphi_{\mathrm{H}}},
$$

Where $P_{\mathrm{H}}$ - nominal rating power of an asynchronous motor;

$U_{\phi н}=U_{\mathrm{c}}$, where $U_{\mathrm{c}}$ - supply voltage.

2. No-load current ratio $\frac{I_{\phi 0 \mathrm{H} \Delta}}{I_{\phi \mathrm{H} \Delta}}$.

3. According to Figure 3 we can determine the ratio $\frac{I_{2 \mathrm{H}}^{\prime}}{I_{\phi \mathrm{H} \Delta}}$ in view of found ratio $\frac{I_{\phi 0 \mathrm{H} \Delta}}{I_{\phi \mathrm{H} \Delta}}$, where $I_{2 \mathrm{H}}^{\prime}$ - adjusted current of a rotor for nominal ratings.

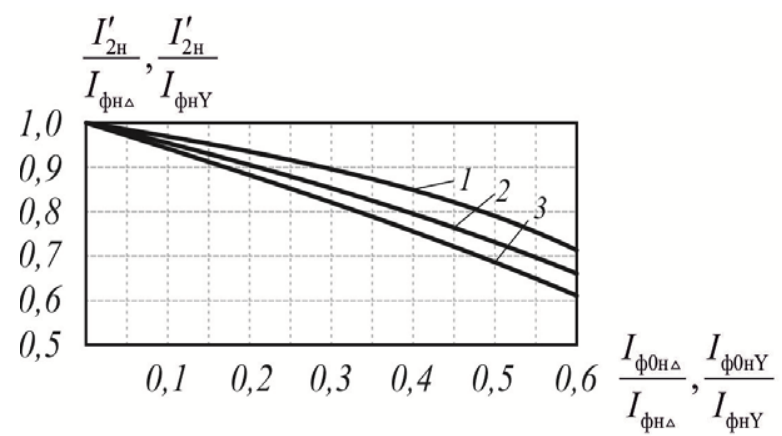

Fig. 3. Correlation between the ratio of adjusted current of an asynchronous motor rotor and the no-load current ratio under different maximum torque:

$1-b_{\text {н }}=3,0 ; 2-b_{\text {н }}=2,0 ; 3-b_{\text {н }}=1,6$.

4. Ratio of adjusted current of a rotor $\frac{I_{2}^{\prime}}{I_{2 \mathrm{H} \Delta}^{\prime}}$.

$$
\frac{I_{2}^{\prime}}{I_{2 \mathrm{H} \Delta}^{\prime}}=\sqrt{k_{\mathrm{H}} \frac{b_{\mathrm{H}}+\sqrt{b_{\mathrm{H}}^{2}-1}}{b_{\mathrm{c} \Delta}+\sqrt{b_{\mathrm{c} \Delta}^{2}-1}}},
$$

where $I_{2}^{\prime}$ - adjusted current of a rotor, when $k_{\mathrm{H}}<1$ and "delta" connection;

$b_{\mathrm{c}}$ - maximum torque ratio under off-nominal load, voltage and frequency.

$$
b_{\mathrm{c} \Delta}=\frac{b_{\mathrm{H}} k_{u}^{2}}{k_{\mathrm{H}} k_{f}^{2}},
$$

where $k_{u}$ - coefficient of voltage variation. For "delta" connection $k_{u}=1$.

$k_{f}$ - coefficient that is set to unity for the $50 \mathrm{~Hz}$ mains frequency, i.e. in our case $k_{f}=1$. 
5. Power factor $\cos \varphi_{\Delta}^{\prime}\left(\varphi^{\prime}\right.$ - phase of adjusted current of a rotor relative to voltage $U_{1}$ ).

$$
\cos \varphi_{\Delta}^{\prime}=\sqrt{\frac{b_{c \Delta}+\sqrt{b_{c \Delta}^{2}-1}}{2 b_{c \Delta}}}
$$

Therefore:

$$
\sin \varphi_{\Delta}^{\prime}=\sqrt{1-\cos \varphi_{\Delta}^{\prime 2}}
$$

6. Reactive power $Q_{\mathrm{H} \Delta}$ at a nominal voltage of mains and load factor $k_{\mathrm{H}}<1$.

$$
Q_{\mathrm{H} \Delta}=3 U_{\phi \mathrm{H} \Delta} I_{\phi \mathrm{H} \Delta}\left(\frac{I_{2 \mathrm{H}}^{\prime}}{I_{\phi \mathrm{H}}} \cdot \frac{I_{2}^{\prime}}{I_{2 \mathrm{H} \Delta}^{\prime}} \sin \varphi_{\Delta}^{\prime}+\frac{I_{\phi 0 \mathrm{H}}}{I_{\phi \mathrm{H} \Delta}}\right) .
$$

7. Stator phase current, when $k_{\mathrm{H}}<1$

$$
I_{1 \phi \Delta}=I_{\phi \mathrm{H} \Delta} \sqrt{\begin{array}{l}
\left(\frac{I_{2 \mathrm{H}}^{\prime}}{I_{\phi \mathrm{H}}} \cdot \frac{I_{2}^{\prime}}{I_{2 \mathrm{H} \Delta}^{\prime}} \sin \varphi_{\Delta}^{\prime}+\frac{I_{\phi 0 \mathrm{H} \Delta}}{I_{\phi \mathrm{H} \Delta}}\right)^{2}+ \\
+\left(\frac{I_{2 \mathrm{H}}^{\prime}}{I_{\phi \mathrm{H} \Delta}}\right)^{2}\left(\frac{I_{2}^{\prime}}{I_{2 \mathrm{H} \Delta}^{\prime}}\right)^{2} \cos \varphi_{\Delta}^{\prime 2}
\end{array}} .
$$

8. Rated slip $S_{\mathrm{H}}$

$$
S_{\mathrm{H}}=\frac{n_{\mathrm{c}}-n_{\mathrm{H}}}{n_{\mathrm{c}}} \cdot 100 \%,
$$

Where $n_{\mathrm{c}}$ - synchronous speed.

9. Total losses $\sum \Delta P_{\Delta}$ in an asynchronous motor, when $k_{\mathrm{H}}<1$.

$$
\begin{aligned}
& \sum \Delta P_{\Delta}=\Delta P_{\text {мех }}+\Delta P_{\text {стали ст. } \Delta}+ \\
& +\Delta P_{\text {об., доб } \Delta}\left(\frac{I_{1 ф \Delta}}{I_{\text {фн } \Delta}}\right)^{2}+\Delta P_{\text {рот }}\left(\frac{I_{2}^{\prime}}{I_{2 \mathrm{H} \Delta}^{\prime}}\right)^{2},
\end{aligned}
$$

Mechanical losses $\Delta P_{\mathrm{Mex}}=0,01 P_{\mathrm{H}}$.

Losses in the phase windings of the stator of an asynchronous motor, including additional losses

$$
\Delta P_{\text {об.доб } \Delta}=3 I_{\text {фн } \Delta}^{2} r_{1}+0,005 P_{\mathrm{H}},
$$

where $r_{1}$ - active resistance of one phase winding of the stator of an asynchronous motor.

With a reasonable degree of accuracy

$$
r_{1}=r_{20}^{\prime}
$$

$r_{20}^{\prime}$ - adjusted active resistance of a rotor, when $s=0$.

$$
r_{20}^{\prime}=\frac{U_{\text {н } \Delta}^{2}\left(1-s_{\text {н }}\right)}{2 c_{1}\left(P_{\text {н }}+\Delta P_{\text {мех }}\right) b_{\text {н }}\left(1+\frac{c_{1}}{s_{\text {н }}\left(b_{\text {н }}+\sqrt{b_{\text {н }}^{2}-1}\right)}\right)},
$$

where $U_{\text {н } \Delta}$ - nominal linear voltage of phase windings of the stator of an asynchronous motor.

Based on the experience of medium-powered asynchronous motor calculations, $c_{1} \approx 1,03$.

Rotor losses $\Delta P_{\text {рот }}=\frac{1,01 P_{\mathrm{H}} s_{\mathrm{H}}}{1-s_{\mathrm{H}}}$.

Losses in stator steel

$$
\Delta P_{\text {стали ст. } \Delta}=\sum \Delta P_{\mathrm{H}}-\left(\Delta P_{\text {мех }}+\Delta P_{\text {об.,доб } \Delta}+\Delta P_{\text {рот }}\right) .
$$

Total loss in nominal mode

$$
\sum \Delta P_{\mathrm{H}}=\frac{P_{\mathrm{H}}\left(1-\eta_{\mathrm{H}}\right)}{\eta_{\mathrm{H}}},
$$

where $\eta_{\mathrm{H}}$ - efficiency factor in nominal mode.

Iron losses do not depend on the load. Therefore, for all $k_{\mathrm{H}}$ the losses will be the identical.

10. Power factor $\cos \varphi_{k_{\mathrm{u}} \Delta}$, when $k_{\mathrm{H}}<1$

$$
\cos \varphi_{k_{\mathrm{H}} \Delta}=\frac{k_{\mathrm{H}} P_{\mathrm{H}}+\sum \Delta P_{\Delta}}{\sqrt{Q_{\mathrm{H} \Delta}^{2}+\left(k_{\mathrm{H}} P_{\mathrm{H}}+\sum \Delta P_{\Delta}\right)^{2}}} .
$$

11. Efficiency factor $\eta_{k_{\mathrm{H}} \Delta}$, when $k_{\mathrm{H}}<1$

$$
\eta_{k_{\mathrm{H}} \Delta}=\frac{P_{\mathrm{H}} \cdot k_{\mathrm{H}}}{P_{\mathrm{H}} \cdot k_{\mathrm{H}}+\sum \Delta P_{\Delta}} .
$$

\section{Proposed calculation algorithm for Star connection}

1. When the "star" connection of the phase windings of the stator of an asynchronous motor is performed, the phase voltage will decrease by a factor of $\sqrt{3}$. The magnetization current will decrease by a factor of $2[5,6]$.

$$
I_{\phi 0 \mathrm{HY}}=\frac{I_{\phi 0 \mathrm{H} \Delta}}{2} .
$$

2. The total power of an asynchronous motor does not depend on the connection pattern of the phase windings of the stator.

Therefore, $3 U_{\phi н} I_{\phi н}=3 U_{\phi н} I_{\phi н}$, where $U_{\phi н}, U_{\phi н}$, $I_{\phi н}, I_{\phi н ~}$ - phase nominal voltages and currents in the stator windings for "delta" and "star" connections, respectively. From here it follows that

$$
I_{\phi \mathrm{H} Y}=\frac{U_{\phi \mathrm{H} \Delta} I_{\phi \mathrm{H} \Delta}}{U_{\phi \mathrm{H}}} .
$$

No-load current ratio $\frac{I_{\phi 0 \mathrm{H} Y}}{I_{\phi \mathrm{H}}}$. 
3. According to Figure 3 we can determine the ratio $\frac{I_{2 \mathrm{H}}^{\prime}}{I_{\phi \mathrm{H}}}$ in view of found ratio $\frac{I_{\phi 0 \mathrm{HY}}}{I_{\phi \mathrm{H}}}$.

4. Ratio of adjusted current of a rotor

$$
\frac{I_{2}^{\prime}}{I_{2 \mathrm{HY}}^{\prime}}=\sqrt{k_{\mathrm{H}} \frac{b_{\mathrm{H}}+\sqrt{b_{\mathrm{H}}^{2}-1}}{b_{\mathrm{cY}}+\sqrt{b_{\mathrm{cY}}{ }^{2}-1}}},
$$

where $I_{2}^{\prime}$ - adjusted current of a rotor, when $k_{\mathrm{H}}<1$ and "star" connection;

$$
b_{\mathrm{cY}}=\frac{b_{\mathrm{H}} k_{\mathrm{u}}^{2}}{k_{\mathrm{H}} k_{f}^{2}},
$$

where $k_{u}=\frac{1}{\sqrt{3}}$, for "star" connection. $k_{f}=1$ for the 50 $\mathrm{Hz}$ mains frequency.

$$
\text { 5. } \quad \cos \varphi_{\mathrm{Y}}^{\prime}=\sqrt{\frac{b_{\mathrm{cY}}+\sqrt{b_{\mathrm{cY}}{ }^{2}-1}}{2 b_{\mathrm{cY}}}} .
$$

Therefore

$$
\sin \varphi_{Y}^{\prime}=\sqrt{1-\cos \varphi_{Y}^{\prime 2}}
$$

6. Reacting power $Q_{\mathrm{HY}}$ for nominal voltage of mains and load factor $k_{\mathrm{H}}<1$.

$$
Q_{\mathrm{HY}}=3 U_{\phi \mathrm{H} \mathrm{Y}} I_{\phi \mathrm{H}}\left(\frac{I_{2 \mathrm{H}}^{\prime}}{I_{\phi \mathrm{H} Y}} \cdot \frac{I_{2}^{\prime}}{I_{2 \mathrm{HY}}^{\prime}} \sin \varphi_{\mathrm{Y}}^{\prime}+\frac{I_{\phi 0 \mathrm{H}}}{I_{\phi \mathrm{H}}}\right) .
$$

7. Stator phase current, when $k_{\mathrm{H}}<1$

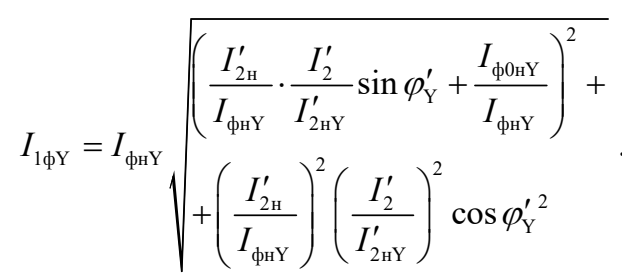

8. Maximum torque ratio in a winding changeover will decrease by a factor of 3 , because the voltage applied to a motor decreases by a factor of $\sqrt{3}$. In order to maintain the operational stability, the load should be three times less than the nominal load. The last condition is met, when $k_{\mathrm{H}} \approx 0,3$. Therefore, when $k_{\mathrm{H}} \approx 0,3$, a slip remains equal to nominal $s_{\mathrm{H}}=\frac{n_{\mathrm{c}}-n_{\mathrm{H}}}{n_{\mathrm{c}}} \cdot 100 \%$.

9. Total losses $\sum \Delta P_{\mathrm{Y}}$ in an asynchronous motor, when $k_{\mathrm{H}}<1$

$$
\begin{aligned}
& \sum \Delta P_{\mathrm{Y}}=\Delta P_{\text {мех }}+\Delta P_{\text {стали ст.Ү }}+ \\
& +\Delta P_{\text {об., добч }}\left(\frac{I_{1 ф \mathrm{Y}}}{I_{\phi н \mathrm{Y}}}\right)^{2}+\Delta P_{\text {рот }}\left(\frac{I_{2}^{\prime}}{I_{2 \mathrm{HY}}^{\prime}}\right)^{2},
\end{aligned}
$$

When $s=s_{\mathrm{H}}$, mechanical losses $\Delta P_{\text {мех }}$ will be identical to losses for "delta" connection. Iron losses $\Delta P_{\text {стали ст.Y }}$ for "star" connection will be three time less than for "delta" connection, because these losses are proportional to the square of induction (voltage). $\frac{U_{\phi \mathrm{H} \Delta}^{2}}{U_{\phi \mathrm{HY}}^{2}}=\frac{380^{2}}{220^{2}}=3$.

Thus, $\Delta P_{\text {стали ст. }}=\frac{\Delta P_{\text {стали ст. }}}{3}$. Rotor losses for "star" connection will be identical to losses for "delta" connection.

$$
\Delta P_{\text {об.добч }}=3 I_{\phi \mathrm{H}}^{2} r_{1}+0,005 P_{\mathrm{H}} .
$$

10. Power factor $\cos \varphi_{k_{\mathrm{H}}}$, when $k_{\mathrm{H}}<1$

$$
\cos \varphi_{k_{\mathrm{H}}}=\frac{k_{\mathrm{H}} P_{\mathrm{H}}+\sum \Delta P_{\mathrm{Y}}}{\sqrt{Q_{\mathrm{HY}}^{2}+\left(k_{\mathrm{H}} P_{\mathrm{H}}+\sum \Delta P_{\mathrm{Y}}\right)^{2}}} .
$$

11. Efficiency factor $\eta_{k_{\mathrm{H}} \mathrm{Y}}$, when $k_{\mathrm{H}}<1$

$$
\eta_{k_{\mathrm{H}}}=\frac{P_{\mathrm{H}} \cdot k_{\mathrm{H}}}{P_{\mathrm{H}} \cdot k_{\mathrm{H}}+\sum \Delta P_{\mathrm{Y}}} .
$$

After performing the calculations for "delta" and "star" connections (when $k_{\mathrm{H}}<1$ ), we shall compare the energy performance of conventional motors and energysaving motors.

\section{Numerical example}

As per abovementioned procedure, calculations are performed for motors with the following conditional technical characteristics.

Conventional asynchronous motor: $P_{\mathrm{H}}=20 \mathrm{~kW}$, $n_{\mathrm{H}}=1460 \mathrm{rpm}, \cos \varphi_{\mathrm{H}}=0,84 \quad$ (Figure 1), $\eta_{\mathrm{H}}=0,875$ (Figure 1), $U_{\mathrm{H} \Delta}=U_{\text {фн } \Delta}=U_{\mathrm{c}}=380 \mathrm{~V}, b_{\mathrm{H}}=2, k_{\mathrm{H}}=0,3$.

Energy-saving motor: $P_{\mathrm{H}}=20 \mathrm{~kW}, n_{\mathrm{H}}=1460 \mathrm{rpm}$, $\cos \varphi_{\mathrm{H}}=0,884$ (Figure 1), $\eta_{\mathrm{H}}=0,92 \quad$ (Figure 1), $U_{\text {н } \Delta}=U_{\text {фн } \Delta}=U_{\text {с }}=380 \mathrm{~V}, b_{\mathrm{H}}=2, k_{\mathrm{H}}=0,3$.

"Delta" winding arrangement of the stator of an energysaving motor

$I_{\text {фн } \triangle}=\frac{20 \cdot 10^{3}}{3 \cdot 380 \cdot 0,884}=19,85 \mathrm{~A}$

$\sin \varphi_{\mathrm{H}}=\sqrt{1-(0,884)^{2}}=0,469$

1. $I_{\phi 0 \mathrm{H} \triangle} \approx 19,85\left(0,496-\frac{0,884}{2+\sqrt{2^{2}-1}}\right)=4,6 \mathrm{~A}$

2. $\frac{I_{\text {ф0н } \triangle}}{I_{\text {фн } \triangle}}=\frac{4,6}{19,85}=0,23$

3. As can be seen from Figure 3: $\frac{I_{2 \mathrm{H}}^{\prime}}{I_{\text {中н }}^{\prime}}=0,91$ 
4. $\frac{I_{2}^{\prime}}{I_{2 \mathrm{H} \Delta}^{\prime}}=\sqrt{0,3 \frac{2+\sqrt{2^{2}-1}}{6,67+\sqrt{(6,67)^{2}-1}}}=0,29$,

where $b_{\mathrm{c}}=\frac{2}{0,3}=6,67$

5. Power factor

$\cos \varphi_{\Delta}^{\prime}=\sqrt{\frac{6,67+\sqrt{(6,67)^{2}-1}}{2 \cdot 6,67}}=0,997$

$\sin \varphi_{\Delta}^{\prime}=\sqrt{1-(0,997)^{2}}=0,077$

6. $Q_{\mathrm{H} \Delta}=3 \cdot 380 \cdot 19,85(0,91 \cdot 0,29 \cdot 0,077+0,23)=$

$=56645 \mathrm{var} \approx 5,66 \mathrm{kVAr}$

7. $I_{1 \phi \Delta}=19,85 \sqrt{\begin{array}{l}(0,91 \cdot 0,29 \cdot 0,077+0,23)^{2}+ \\ +(0,91)^{2} \cdot(0,29)^{2} \cdot(0,997)^{2}\end{array}}=7,18 \mathrm{~A}$

8. $s_{\mathrm{H}}=\frac{1500-1460}{1500} \cdot 100=2,67 \%$

9. $\Delta P_{\text {мех }}=0,01 \cdot 20000=200 \mathrm{~W}$

$\Delta P_{\text {об.доб } \Delta}=3 \cdot(19,85)^{2} \cdot 0,149+0,005 \cdot 20000=276,13 \mathrm{~W}$

$$
\begin{gathered}
r_{1}=r_{20}^{\prime}= \\
=\frac{380(1-0,0267)}{2 \cdot 1,03 \cdot(20000+200) \cdot 2 \cdot\left(1+\frac{1,03}{0,0267\left(2+\sqrt{2^{2}-1}\right)}\right)}= \\
=0,149 \text { OM } \\
\sum \Delta P_{\text {н }}=\frac{20000(1-0,92)}{0,92}=1739,1 \mathrm{~W} \\
\Delta P_{\text {рот }}=\frac{1,01 \cdot 20000 \cdot 0,0267}{1-0,0267}=554,13 \mathrm{~W} \\
\Delta P_{\text {стали ст. }}=1739,1-(200+276,13+554,13)= \\
=708,84 \mathrm{~W}
\end{gathered}
$$$$
\sum \Delta P_{\Delta}=200+708,84+276,13 \cdot\left(\frac{7,18}{19,85}\right)^{2}+554,13 \cdot 0,29^{2}=
$$$$
=991 \mathrm{~W}=0,991 \mathrm{~kW}
$$

10. $\cos \varphi_{k_{\mathrm{H}}}=\frac{0,3 \cdot 20+0,991}{\sqrt{(5,66)^{2}+(0,3 \cdot 20+0,991)^{2}}}=0,778$

11. $\eta_{k_{\mathrm{H}}}=\frac{20 \cdot 0,3}{20 \cdot 0,3+0,991}=0,868$.
Similar calculations are performed for an energysaving motor connected in the Star, as well as for a conventional motor connected in the Star or in the Delta.

\section{Research results}

After having performed a similar calculations for an energy-saving motor and conventional motor, the authors obtained the following results:

- energy-saving motor connected in the Star: $\cos \varphi_{k_{\mathrm{HY}}}=0,851, \eta_{k_{\mathrm{HY}}}=0,888$;

- conventional motor connected in the Delta: $\cos \varphi_{k_{\mathrm{H}} \Delta}=0,712, \eta_{k_{\mathrm{H}} \Delta}=0,74$;

- conventional motor connected in the Star: $\cos \varphi_{k_{\mathrm{HY}}}=0,824, \eta_{k_{\mathrm{HY}}}=0,844$

Thus, application of energy-saving motors instead of conventional motors increases the power factor (when $k_{\mathrm{H}} \approx 0,3$ ) as follows:

$$
\frac{\cos \varphi_{k_{\mathrm{H}} \Delta \ni \mathrm{H}}-\cos \varphi_{k_{\mathrm{H}} \Delta \mathrm{० \sigma}}}{\cos \varphi_{k_{\mathrm{H}} \triangle \mathrm{\sigma} \sigma}} \cdot 100 \%
$$

(where $\cos \varphi_{k_{\mathrm{H}} \triangle \text { эн }}$ - power factor for an energy-saving motor connected in the Delta, $\cos \varphi_{k_{\mathrm{H}} \triangle \mathrm{0 \sigma}}$ - power factor for a conventional motor connected in the Delta).

Numerically: $\frac{0,778-0,712}{0,712} \cdot 100 \%=9,3 \%$.

Therefore: $\frac{\cos \varphi_{k_{\mathrm{H}} \text { Үэн }}-\cos \varphi_{k_{\mathrm{H}} \text { Үоб }}}{\cos \varphi_{k_{\mathrm{H}} \text { Үоб }}} \cdot 100 \%=$

$=\frac{0,851-0,824}{0,824} \cdot 100 \%=3,28 \%$.

$\frac{\eta_{k_{\mathrm{H}} \triangle \text { эн }}-\eta_{k_{\mathrm{H}} \triangle \text { Об }}}{\eta_{k_{\mathrm{H}} \triangle \text { Об }}} \cdot 100 \%=\frac{0,868-0,74}{0,74} \cdot 100 \%=17,3 \%$.

$\frac{\eta_{k_{\mathrm{H}} \text { Үэн }}-\eta_{k_{\mathrm{H}} \text { Үоб }}}{\eta_{k_{\mathrm{H}} \text { Үоб }}} \cdot 100 \%=\frac{0,888-0,844}{0,844} \cdot 100 \%=5,21 \%$.

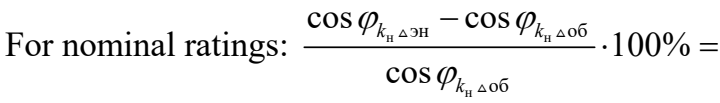
$=\frac{0,884-0,84}{0,84} \cdot 100 \%=5,24 \%$

$\frac{\eta_{k_{\mathrm{H}} \triangle \text { эн }}-\eta_{k_{\mathrm{H}} \Delta \text { Об }}}{\eta_{k_{\mathrm{H}} \triangle \text { об }}} \cdot 100 \%=\frac{0,92-0,875}{0,875} \cdot 100 \%=5,14 \%$

Thus, application of energy-saving motors significantly improves the energy performance of an electrical drive of the equipment for repair of railway rolling stock, considerable part of which works with a load factor $k_{\mathrm{H}}=0,2 \ldots 0,3$. 


\section{Summary}

1. The proposed methods and algorithm for energy performance calculation applied during replacement of conventional asynchronous motors with energy-saving ones and changeover of stator winding from Delta to Star with a load factor $k_{\mathrm{H}} \approx 0,2 \ldots 0,3$ can be applied when performing the technical and economic calculations to decide the question of feasibility of the energy-saving motors at the enterprises, which carry out repairs of various equipment.

2. Application of energy-saving asynchronous motors instead of conventional ones allows to improve the energy performance of electric drives of non-standard technological equipment meant for repair of railway rolling stock from about $3 \%$ to $17 \%$ for mediumpowered motors.

3. The reported numerical values of power factors and efficiency factors, their ratios for energy-saving and conventional asynchronous motors are logically sound in the context of electrical machine theory, which confirms the accuracy of the proposed methodology for determining these energy indicators when the electric drive load of various devices is about 30\% compared with the nominal ratings.

4. With due regard for the continuous rise in the electricity prices, energy-saving motors can be an excellent reserve for the improvement of energy performance of various electric drives at the repair facilities, especially if under technological conditions the load factor periodically decreases to $0.2 \ldots 0.3$ over extended periods.

\section{References}

1. Zakladnyj O. M., Prakhovnyk A. V., Solovej O. I. Energy saving by means of an industrial electric drive: a manual. Kyiv: Kondar, 408 p. (2005)/

2. Non-standard technological equipment for the repair of locomotives, cars and motor-car rolling stock. "Trans-Atom" LLC Available online at: https://trans-atom.com/page/about.html

3. DSTU 3886 - 99. Energy Saving. Electric drive systems. Method of analysis and selection. Kyiv: Derzhstandart Ukrainy, - 54 p. (2000).

4. Ways of energy saving Available online at: https://lektsii.com/1-51568.html

5. Syromjatnikov I. A. Modes of operation of asynchronous motors. Moscow: Gosenergoizdat, 528 p. (1963).

6. Syromjatnikov I. A. Modes of operation of asynchronous and synchronous motors. Moscow: Energoatomizdat, 240 p. (1984).

7. Dubynec L. V, Momot O.I., Marenych O.L. Electric machines. Transformers Asynchronous Machines: Basic Guide Dnipropetrovsk: Dnipropetrovsk National University of Railway Transport Publishing, 208 p. (2004).

8. Dubynets L. V, Marenych O. L, Baliichuk O. Yu., Kortohus A. S. Energy saving during operation of equipment with non-controlled electric drive in locomotive depot Science and transport progress. Bulletin of the Dnepropetrovsk National University of Railway Transport. № 5 (65), P. $54-63$.

9. Baliichuk O. Yu., Dubynets L. V, Marenych O. L, Lysenko O. O Increasing of power factor of electric drives of non-standard equipment of enterprises for repair of rolling stock of railways. Electrification of transport № 14, P. 31 - 36.

10. .Afanasov A. M, Shapovalov O. S. Increasing of power efficiency of traction electric machines tests Electrification of transport № 14, P. 28 - 30.

11. Lokarev V. Y. On the system of evaluating the energy efficiency of a modern electric drive. Bulletin of the National University of Shipbuilding № 6, P. $75-81$

12. V. V. Dzhedzhula, I. Yu. Yepifanova. Innovations in the system of management of energy saving of industrial. Available online at: http://economyandsociety.in.ua

13. Lei Li, Haihong Huang, Zhifeng Liu Xinyu Li, Matthew J. Triebe, Fu Zhao. An energy-saving method to solve the mismatch between installed and demanded power in hydraulic press. Journal of Cleaner Production. - Vol. 139. - P. 636-645 (2016). doi: 10.1016/j.jclepro.2016.08.063.

14. M. M. Shaikh, A. J. Memon, M. Hussain. Data on electrical energy conservation using high efficiency motors for the confidence bounds using statistical techniques Available online at: https://www.ncbi.nlm.nih.gov/pmc/articles/PMC492 5456/. doi:10.1016/j.dib.2016.06.004

15. A. J. Memon, M. M. Shaikh. Confidence bounds for energy conservation in electric motors: An economical solution using statistical techniques. Energy. - Vol. 109. P. 592-601. (2016). doi:10.1016/j.energy.2016.05.014

16. Energy Saving Motors. Available online at: http://europromtech.ru/energosberegaushiedvigateli.html

17. Helduser, S. Electric-hydrostatic drive an innovative energy-saving power and motion control system. Proceedings of the Institution of Mechanical Engineers, Part I: Journal of Systems and Control Engineering, 213(5), 427-437. (1999). https://doi.org/10.1243/0959651991540250

18. L. Zarri, M. Mengoni, A. Tani, G. Serra, D. Casadei, J. O. Ojo, Control schemes for field weakening of induction machines: A review, Electrical Machines Design Control and Diagnosis (WEMDCD) 2015 IEEE Workshop on, pp. 146-155 (2015).

19. Bogdan Pryymak, Manuel Moreno-Eguilaz, Characteristics of induction motor drives with torque maximization in field weakening region, Electrical and Computer Engineering (UKRCON) 2017 IEEE First Ukraine Conference on, pp. 508513 (2017).

20. Shuying Yang, Dawei Ding, Xi Li, Zhen Xie, Xing Zhang, Liuchen Chang, A Novel Online Parameter Estimation Method for Indirect Field Oriented Induction Motor Drives, Energy Conversion IEEE Transactions on, vol. 32, no. 4, pp. 1562-1573 (2017). 